\title{
Design and challenges for a tsunami early warning system in the Marmara Sea
}

\author{
Öcal Necmioğlu
}

\begin{abstract}
Since 1900, around 90,000 people have lost their lives in 76 earthquakes in Turkey, with a total affected population of around 7 million and direct losses of around 25 billion USD. Based on a time-dependent model that includes coseismic and post-seismic effects of the 1999 Kocaeli earthquake with moment magnitude Mw = 7.4, Parsons (J Geophys Res. 109, 2004) concluded that the probability of an earthquake with Mw > 7 in the Sea of Marmara near Istanbul is 35 to $70 \%$ in the next 30 years. According to a 2011 study, an earthquake with Mw $=7.25$ on the Main Marmara Fault is expected to heavily damage or destroy 2 to $4 \%$ of around 1,000,000 buildings in Istanbul with a population around 13 million, with 9 to $15 \%$ of the buildings receiving medium damage and 20 to $34 \%$ of the buildings damaged lightly (Erdik, Science 341:72, 2013). In the absence of adequate post-earthquake assembly areas especially in the heavily urbanized Istanbul, it is evident that after a major earthquake, especially in the coastal parts of the city, citizens would be storming to landfill assembly and recreational areas. Besides earthquakes, around 30 tsunamis have been reported by Altınok et al. (Natural Hazards Earth System Science 11:273-293, 2011) in the Marmara Sea. Among those, catastrophic earthquakes such as 1509, 1766, and 1894 resulted in considerable tsunamis and some damage. The latest tsunami observed in Marmara was due to a triggered submarine landslide of the $1999 \mathrm{Mw}=7.4$ Kocaeli earthquake which led to reported run-up heights of 1-3 $\mathrm{m}$ in most places (Tinti et al., Marine Geology 225:311-330, 2006). In this study, I propose a design for a tsunami warning system specific for the Marmara region that is strongly coupled with the earthquake early warning system (due to the short arrival times of tsunami) and stakeholders of the tsunami mitigation activities, such as local and regional components of disaster and emergency management and civil protection units, to ensure that the citizens would remain away from the coastline in case of a large earthquake, while discussing associated challenges such as decoupled earthquake and tsunami mitigation activities in the Marmara region.
\end{abstract}

Keywords: Marmara, Tsunami early warning

\section{Earthquake risk in Marmara}

Since 1900, around 90,000 people have lost their lives in 76 earthquakes in Turkey, with a total affected population of around 7 million and direct losses of around 25 billion USD. Based on a time-dependent model that includes coseismic and post-seismic effects of the 1999 Kocaeli earthquake with moment magnitude $(\mathrm{Mw})=7.4$, Parsons (2004) concluded that the probability of an earthquake with $\mathrm{Mw}>7$ in the Sea of Marmara near Istanbul is 35 to $70 \%$ in the next 30 years (Erdik 2013). A recent study also confirmed that the probability of occurrence of an earthquake of

Correspondence: ocal.necmioglu@boun.edu.tr

Kandilli Observatory and Earthquake Research Institute, Boğaziçi University, Istanbul, Turkey

\section{Springer}

(c) 2016 Necmioğlu. Open Access This article is distributed under the terms of the Creative Commons Attribution 4.0 International License (http://creativecommons.org/licenses/by/4.0/), which permits unrestricted use, distribution, and reproduction in any medium, provided you give appropriate credit to the original author(s) and the source, provide a link to the Creative Commons license, and indicate if changes were made. magnitude greater than 7 is high in the Marmara region. While most of the large events are characterized by epicenters located in the central or eastern parts of the Sea of Marmara, the possibility of a westerninitiated rupture propagating eastwards cannot be ruled out (Aochi and Ulrich 2015). Bohnhoff et al. (2013) indicated that the remarkable sequence of large earthquakes over the last century in the North Anatolian Fault Zone (NAFZ) has left an earthquake gap south of Istanbul and beneath the Marmara Sea, which has not been filled for 250 years. They argue, furthermore, that the Prince Islands segment is locked and is therefore a potential nucleation point for another Marmara segment earthquake. This hypothesis has been further supported by Ergintav et al. (2014), 
where they reported direct observations of strain accumulation on the Prince Islands segment, constraining the slip deficit rate to $10-15 \mathrm{~mm} /$ year, concluding that the Prince Islands segment is most likely to generate the next $M>7$ earthquake along the Sea of Marmara segment of the NAFZ. According to a 2011 study, an earthquake with $\mathrm{Mw}=7.25$ on the Main Marmara Fault is expected to heavily damage or destroy 2 to $4 \%$ of around 1,000,000 buildings in Istanbul with a population around 13 million, with 9 to $15 \%$ of the buildings receiving medium damage and 20 to $34 \%$ of the buildings damaged lightly (Erdik 2013).

\section{Historical tsunamis in the Marmara Sea}

The historical tsunamis in the Marmara Sea has been described in detail in various references (Mihailovic 1927; Gundogdu 1986; Oztin and Bayülke 1991; Oztin 1994; Ambraseys and Finkel 1987, 1995; Altınok and Ersoy 2000; Arel and Kiper 2000; Altınok et al. 2001, 2003, 2011; Yalciner et al. 2001a, b, c; Ambraseys 2002; Cetin et al. 2004; Rothaus et al. 2004; Tinti et al. 2006; Meral Ozel et al. 2011). Among those, the most important ones are the Istanbul earthquakes on 10 September 1509, on 22 May 1766, and on 10 July 1894; the Sarkoy-Murefte earthquake on 9 August 1912; and the 17 August 1999 Kocaeli earthquake. Please refer to Fig. 1 for the locations referred throughout the text.

The Istanbul earthquake on 10 September 1509 was one of the largest and most destructive earthquakes of the last five centuries in the Eastern Mediterranean. It occurred in the Marmara Sea and caused damage over the entire Marmara region, with maximum damage in Istanbul. The earthquake killed 4000-5000 people in the city and destroyed over 1000 houses. Along the coast, the sea flooded the shores and waves crashed against the walls of the old city (Ambraseys and Finkel 1995). In some locations, waves overtopped the walls and caused flooding. The wave height was most probably more than $6.0 \mathrm{~m}$, and the magnitude of the earthquake was close to 8.0 (Oztin and Bayülke 1991).

During the 22 May 1766 Istanbul earthquake, which was destructive mostly around Eastern Marmara and its associated tsunami also caused considerable damage in Gemlik Bay in Eastern Marmara (Ambraseys and Finkel

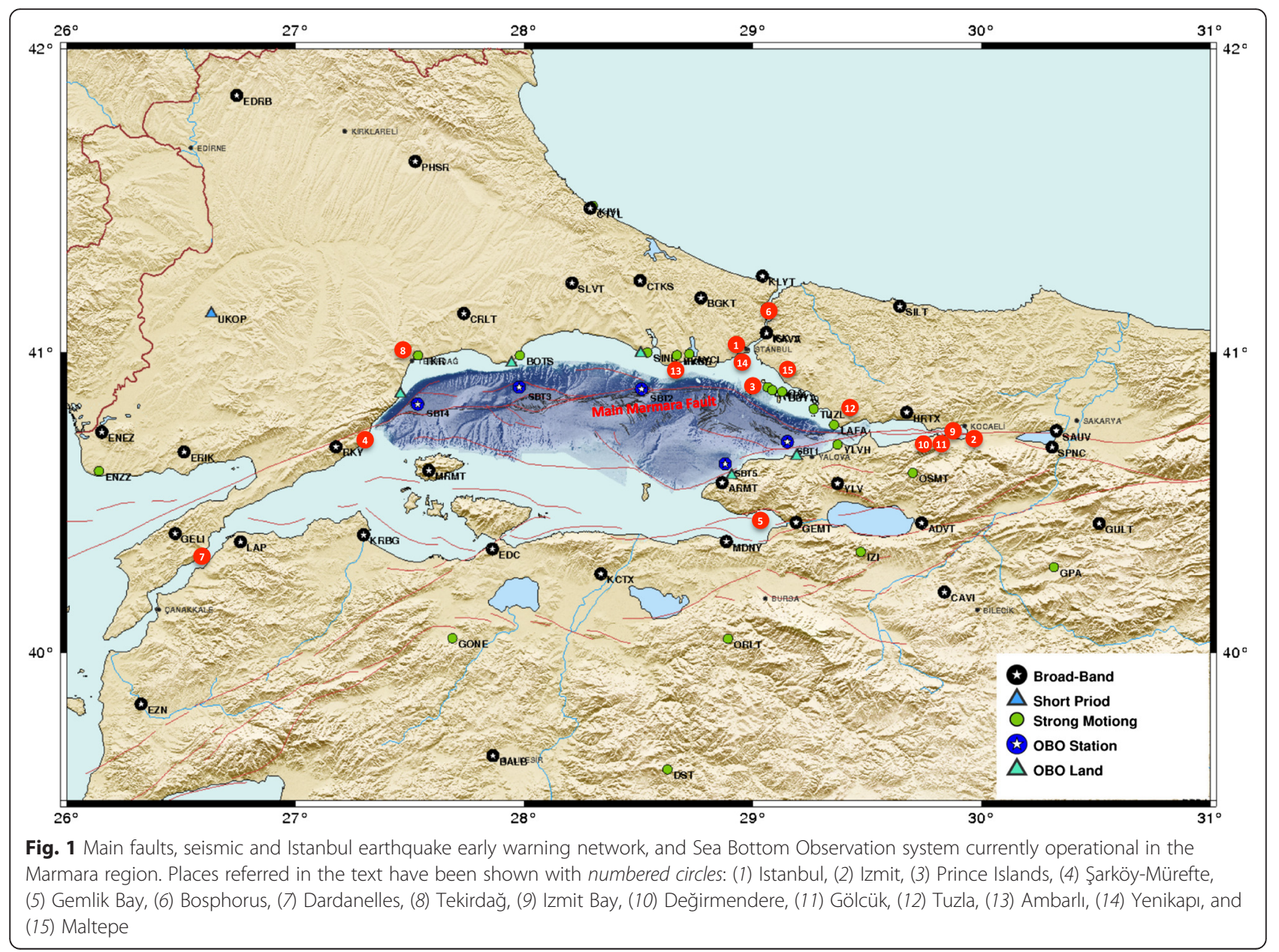


1995; Altınok et al. 2003), the waves were also recognized in Istanbul and the inner parts of the Bosphorus (Cesmi-zade 1766).

Another earthquake in Istanbul occurred on 10 July 1894, damaged Istanbul and the surrounding area, and was felt in the Eastern Balkans, Crete, and Central Anatolia. The earthquake killed 474 people and injured 482 more and destroyed 1773 houses (Oztin 1994). According to Mihailovic (1927), the sea rose up and inundated $200 \mathrm{~m}$ and, after a few disturbances, became normal.

The Sarkoy-Murefte earthquake on 9 August 1912 is the latest event to the west before the 1999 Kocaeli earthquake. It occurred on the active Ganos Fault zone in Western Marmara and was one of the largest earthquakes in the Balkans. The historical data, geological field surveys, and offshore geophysical investigations have shown that the 1912 earthquake produced a tsunami. In addition, a seabed dislocation, the source of 1912 tsunami, can also be assigned to the sediment slumps appearing in the form of echelon landslide prisms along the southern slopes of the West Marmara Trough (Altınok et al. 2003). The most significant findings about tsunami event were classified depending on their observation place (Altınok et al. 2003). Most of the coastal area of the Dardanelles were inundated by sea waves (Mihailovic 1927; Gundogdu 1986). In Tekirdag in Western Marmara, the sea receded after the earthquake along the coast and then returned with some force causing no damage (Ambraseys and Finkel 1987).

It has been shown that the 1999 Kocaeli earthquake with $\mathrm{Mw}=7.4$ has also created a tsunami in Izmit Bay (Altınok et al. 2001; Tinti et al. 2006). Post-event field surveys and interview of eyewitnesses conducted soon after the tsunami occurrence by several teams enabled to determine the coastal areas of major wave impact and to quantify the run-up heights and the sea penetration lengths in all the affected places. The tsunami observation times were close to the main shock. Almost in all places, the tsunami was seen to cause the sea to withdraw first and then to overcome the usual shoreline and inundate land. The observed tsunami run-up heights were modest and typically in the range of $1-3 \mathrm{~m}$. The tsunami was damaging, but not catastrophic. In some places, it was strong enough to carry boats and vessels on land (Altınok et al. 2001; Rothaus et al. 2004). A detailed description of the tsunami observations can be found in the works by Yalciner et al. (2000, 2001a, b, c) and by Altınok et al. (2001) and has been integrated in a study by Rothaus et al. (2004) that focuses on the effects in the southern coast of Izmit Bay (Tinti et al. 2006). The tsunami was exceptionally violent only in the town of Degirmendere. Here, measured wave runups exceeded $4 \mathrm{~m}$, but several eyewitnesses state that the wave reached the second floor of the buildings in the waterfront (observation was made by the joint Italian-Turkish team that included Stefano Tinti, Alberto Armigliato, Ahmet Cevdet Yalciner, and Yildiz Altınok; Tinti et al. 2006), and some other estimate a height of about $15 \mathrm{~m}$ (Rothaus et al. 2004). Ships moored in the port of Degirmendere were severely affected by the waves, and seamen reported that the attacking wave was probably larger than $10 \mathrm{~m}$ (Altınok et al. 2001). Perhaps, the same large wave struck ships moored in the next town of Kavakli, east of Golcuk: here, the tsunami came over a ship reaching a height of more than $15 \mathrm{~m}$, according to witnesses' rough evaluation (Rothaus et al. 2004). The anomalous violence of the tsunami in the limited area around Degirmendere is the consequence of an additional local tsunamigenic source that was identified in a slump (Arel and Kiper 2000; Altınok et al. 2001; Cetin et al. 2004; Tinti et al. 2006).

\section{Tsunami characteristics in the Marmara Sea from the point of early warning}

In a previous study conducted by OYO Pacific Consultants International Corporation et al. (2002), more than 50 cases of tsunami sources due to the movement of the NAFZ in the Marmara Sea, landslide along the cliffs, and their combinations had been considered. The study showed that the estimated tsunami heights due to the NAFZ segments with small vertical displacement could not explain the historical tsunami heights. On the other hand, the estimated tsunami heights due to submarine landslides alone are not big but sharp at local areas. The tsunami heights due to the combination of the movement of the NAFZ and a triggered submarine landslide can mostly explain the historical tsunami records (Kaneko 2009). A possible future earthquake occurring in the Marmara Sea has a direct tsunamigenic potential and, furthermore, may set in motion submarine masses (landslides or slumps), with additional possibility to produce tsunamis (Yalciner et al. 2001a, b, c; Hebert et al. 2005; Tinti et al. 2006). The fact that a submarine landslide triggered by an earthquake could be the primary cause of a tsunami in the Marmara Sea, as indicated by the historical catalogues and previous studies, shows the importance of an earthquake early warning-coupled tsunami warning system without waiting for any focal mechanism parameter determination that may lead to an underestimation of the tsunami risk in the case of a strike-slip fault, which is the dominant seismotectonic characteristic of the Marmara Sea. This argument could be further supported by the fact that tsunami arrival times in the Marmara Sea range between 5 and 60 min (Fig. 2). 


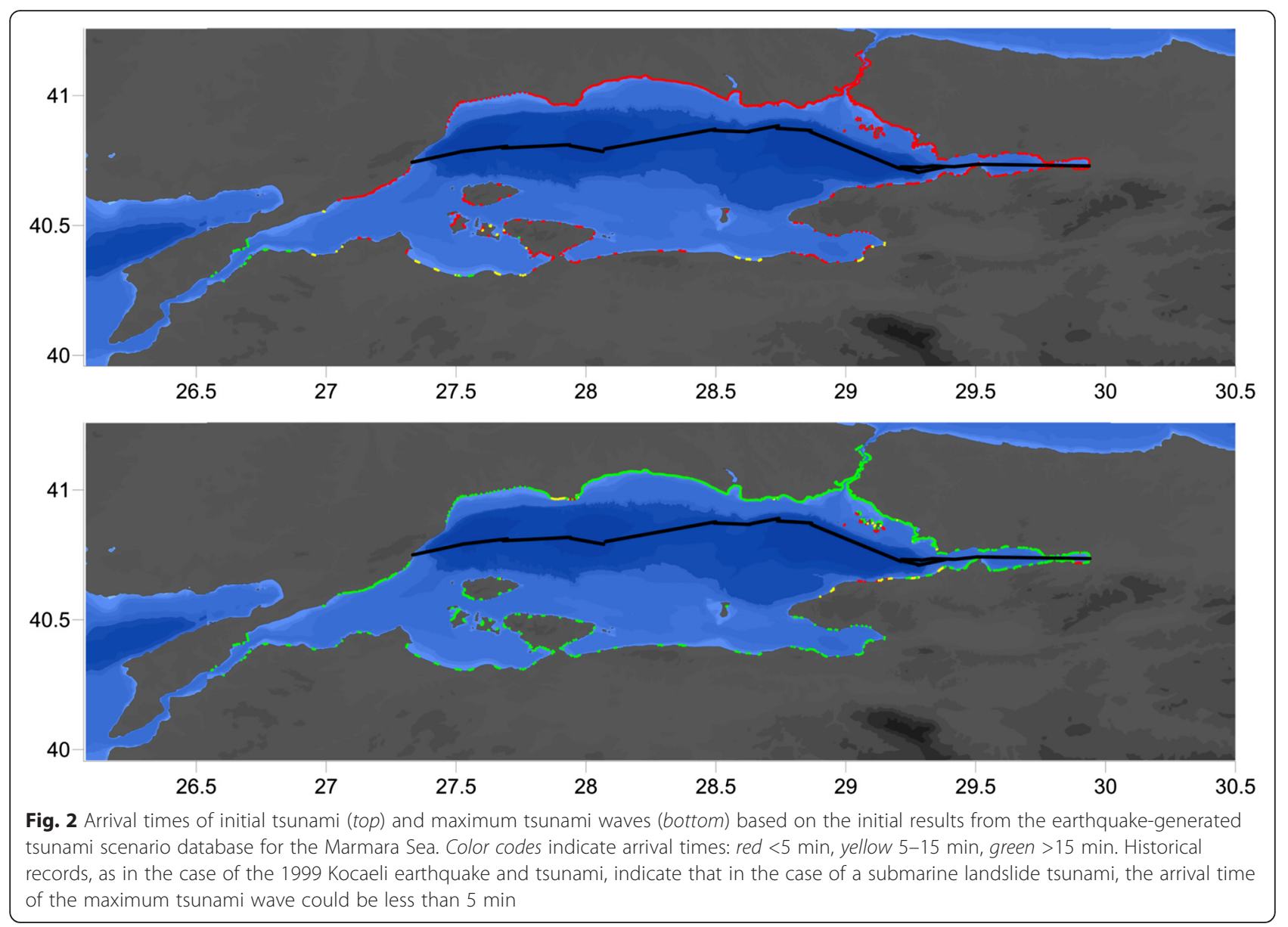

\section{Elements at risk for a credible tsunami event for Istanbul}

Hancilar (2012) identified the elements at risk for a credible tsunami event for Istanbul by utilizing inundation maps resulting from probabilistic tsunami hazard analysis for a $10 \%$ probability of exceedance in 50 years in combination with the geo-coded inventories of building stock, lifeline systems, and demographic data. While noting that the built environment on Istanbul's shorelines exposed to tsunami inundation comprises residential, commercial, industrial, public buildings (governmental/municipal, schools, hospitals, sports, and religious), infrastructure (car parks, garages, fuel stations, electricity transformer buildings), and military buildings, as well as piers and ports, gas tanks and stations, and other urban elements (e.g., recreational facilities), he further argued that along the Marmara Sea shore, Tuzla (Fig. 1) shipyards and important port and petrochemical facilities at Ambarlı (Fig. 1) are expected to be exposed to tsunami hazard. Hancilar (2012) also stated that significant lifeline systems of the city of Istanbul such as natural gas, electricity, telecommunication, and sanitary and waste-water transmission are also under the threat of tsunamis and in terms of social risk, and he estimated that there are about 32,000 inhabitants exposed to tsunami hazard. It should be emphasized, however, that Hancilar (2012) considered only seismic sources and as himself pointed out, that while it could be said that the eastern coasts of Istanbul are more hazardous than the western coastlines, numerical modeling and hazard assessment considering submarine landslides might result in different inundations on the shorelines of the city. In other words, his conclusions could be considered as corresponding to the best-case tsunami scenario and the risk would be considerably higher in the case of a tsunami due to coseismic submarine landslide.

\section{Earthquake and tsunami preparedness}

Disaster Preparedness Education Unit (DPEU) of Kandilli Observatory and Earthquake Research Institute (KOERI) has been contributing to the preparation of the community to a destructive earthquake through increased disaster awareness, local preparedness, first-response organization, and skills across the country. DPEU is already involved in developing, supervising, and evaluating training programs on disaster risk management; preparation and dissemination of training materials such as 
booklets, forms, presentations, videos, and CDs; creation of a pool of trainers within KOERI; providing training programs at the national level in cooperation with other agencies if necessary; and organizing national and international seminars, workshop, and public activities. DPEU earthquake training packages are Basic Disaster Awareness, Community Disaster Volunteers, Nonstructural Risk Mitigation, and Structural Awareness for Seismic Safety. DPEU's experience and know-how on earthquake awareness, preparedness, and mitigation is being used to reach the same level of maturity concerning the tsunami hazard education and awareness-raising activities. In this spirit, KOERI has participated in the North-Eastern Atlantic and Mediterranean Tsunami Information Centre (NEAMTIC) Project on a selffunded base for the translation of selected material in Turkish, such as educational poster, website/virtual library interface, and coastal inundation online course, of good and guidelines/poster on hotel evacuation practices compendium. In addition, within the EC-FP7 Project ASTARTE and "MarDiM: Earthquake and Tsunami Disaster Mitigation in the Marmara Region and Disaster Education in Turkey" project supported by JICA/SATREPS, KOERI executed an assessment of tsunami studies conducted in Turkey that includes published articles, oral and poster presentations, books, and several awareness materials produced. Furthermore, studies around the globe have also been evaluated, and particular emphasis was given to preparedness studies in Japan. In direct consultation with a group of Japanese experts, experiences and preparedness material produced in Japan, such as booklets, videos, and animations, have also been studied. As a result of this, a "tsunami information booklet" has been prepared as an educational material. An educational short video has also been prepared in consultation with Japanese experts. To assess the effectiveness of the produced material, a pre- and post-questionnaire with 10 questions have been prepared, which comprised three sections as personal attributes, general questions, and understanding tsunami. This questionnaire has been applied to pupils visiting KOERI's Disaster Preparedness Education Unit.

A lot has been accomplished in Turkey after the 1999 Kocaeli earthquake in terms of earthquake preparedness. This is especially valid for the Istanbul Metropolitan Area, where comprehensive re-urbanization is taking place to ensure non-earthquake-proof buildings are replaced with earthquake-proof buildings. The criticality of this re-urbanization is evident according to a 2011 study, which shows that an earthquake with $\mathrm{Mw}=7.25$ on the Main Marmara Fault is expected to heavily damage or destroy 2 to $4 \%$ of around 1,000,000 buildings in Istanbul with a population around 13 million, with 9 to $15 \%$ of the buildings receiving medium damage and 20 to $34 \%$ of the buildings damaged lightly (Erdik 2013).
While the full analysis of the relation of the urban planning and earthquake hazard is beyond the scope of this study, it is important to re-emphasize that post-disaster provision of shelter, food, medical, and social services to people is among the key elements of disaster management and recovery plans. For almost more than a decade now, Istanbul Metropolitan City has been undergoing a heavy re-urbanization, where most of the open spaces that have been identified after the 1999 Kocaeli earthquake as post-disaster evacuation and assembly areas have been opened for large-scale constructions for shopping malls and luxury residences. While the exact number and information on how many areas originally designated as assembly zones have been transformed into other types of locations is lacking, reports of non-governmental organizations claim that more than half of these areas are on stake. In an obvious effort to compensate this loss, the Istanbul Metropolitan Municipality created masslandfill areas without bore-pile installation, both in the European and Asian coasts of the city, in Yenikapı and Maltepe districts, with 0.5 and $1.5 \mathrm{~km}^{2}$ areas, respectively (Fig. 3). These areas have been introduced as open public spaces and recreational areas, also to be used as assembly areas after an earthquake. In addition, the question of how these landfill areas will respond to the earthquake load remains still open. Already in 2002, the total area of the open spaces for evacuation and postdisaster assembly purposes had been identified as less than $25 \%$ of demand especially in the Maltepe area situated already in a region where the thickness of the layer subject to a possible liquefaction is determined as between 4 and $50 \mathrm{~m}$. The maximum expected tsunami wave height was simulated as $5.5 \mathrm{~m}$, and inundation distance is less than $150 \mathrm{~m}$ (excluding newly established landfill areas). The expected lifetime of a tsunami in Istanbul is between 90 and $120 \mathrm{~min}$ (OYO Pacific Consultants International Corporation et al. 2002). Concerning the fact that post-disaster evacuation and assembly area maps are publicly available neither from the Civil Protection Authority nor from the Istanbul Metropolitan Municipality, it is evident that after a major earthquake, especially in the coastal parts of the city, citizens would be storming to these landfill areas in the absence of post-disaster assembly areas inland. In case of a tsunami triggered by an earthquake or submarine landslide due to an earthquake, the logistical plans relying to these landfill areas for disaster management would be expected to collapse.

\section{KOERI's tsunami warning system with regional services}

KOERI's Regional Earthquake and Tsunami Monitoring Center (RETMC) is $24 / 7$ operational National Tsunami 


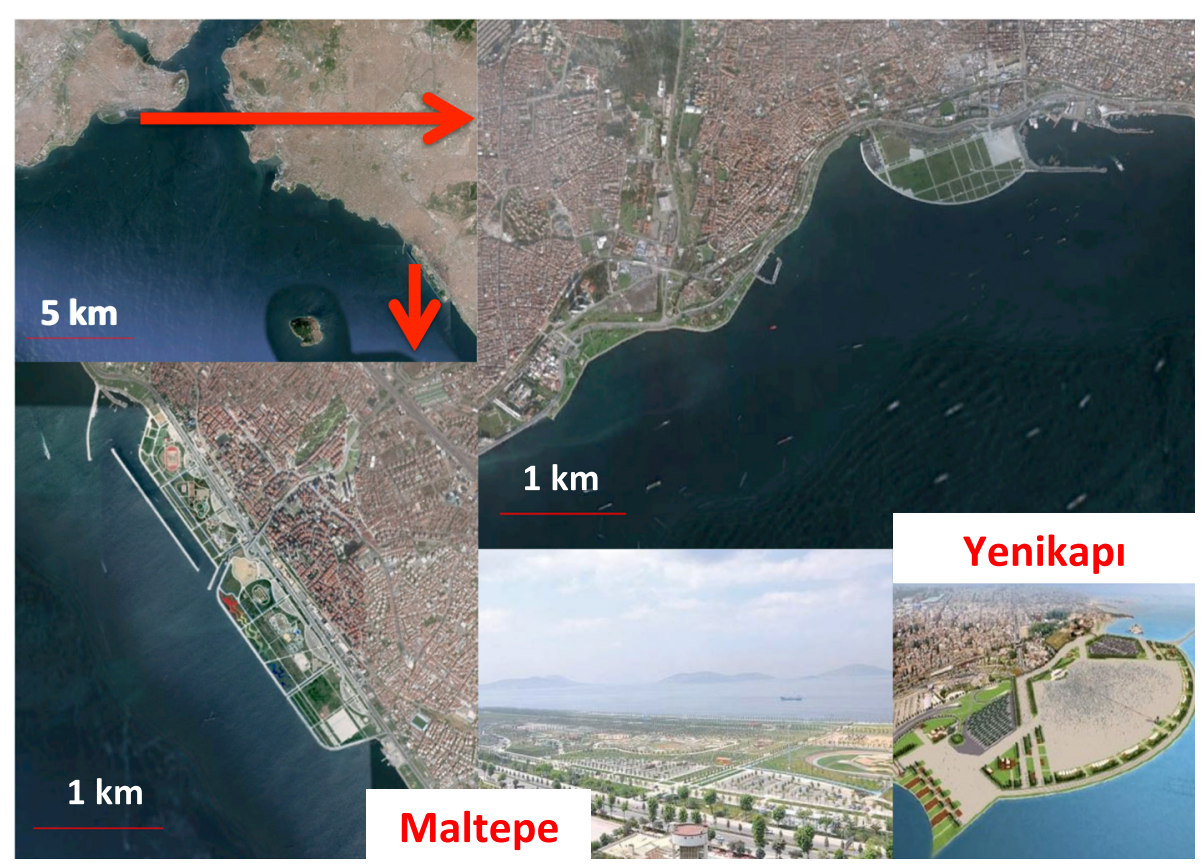

Fig. 3 Maltepe and Yenikapı landfill areas of Istanbul Metropolitan City. These areas have been introduced as open public spaces and recreational areas, also to be used as assembly areas after an earthquake

Warning Center (NTWC-TR) providing services to the Eastern Mediterranean, Aegean, and Black Seas since 1 July 2012 as a Candidate Tsunami Service Provider (CTSP-TR) under the framework of the Intergovernmental Coordination Group for the Tsunami Early Warning and Mitigation System in the North-eastern Atlantic, the Mediterranean and connected seas (ICG/NEAMTWS) initiative. Duty officers of the RETMC perform internal tests of the tsunami warning system on a daily basis based on pre-determined set of scenarios. In addition, KOERI performs regular communication test exercise with other CTSPs and participates in NEAMTWS Communication and Tsunami Exercises. The system relies on decision criteria based on the $\mathrm{Mw}$ and the hypocenter of the earthquake and could be supported with the use of a pre-calculated tsunami scenario database, where especially the accurate calculation of the Mw poses a critical element of the accurate early warning. This approach is applicable to basin-scale-generated tsunamis and currently adopted by the NEAMTWS.

\section{Temporal boundary conditions for a near-field tsunami early warning system}

The temporal boundary conditions of a tsunami early warning system is clearly described in Papadopoulos and Fokaefs (2013). According to them, the operative efficiency of a tsunami warning system in near-field conditions depends on the times needed for seismic signal communication, $t_{\mathrm{S}}$, and for evacuation, $t_{\mathrm{E}}$, where each is composed by more than one time components. Seismic signal communication incorporates the time needed for the determination of the earthquake focal parameters, $t_{\mathrm{SD}}$, and the time needed for the tsunami decisionmaking, $t_{\mathrm{TD}}$, as well as the time, $t_{\mathrm{ST}}$, needed for the transmission of the earthquake information and of the result of the tsunami decision to the operational center of the civil protection. In addition, the time for evacuation incorporates another two time components. The first is the time, $t_{\mathrm{WT}}$, needed to transmit warning information from the civil protection to the population. Finally, after transmitting this information, there is a need to allow for some time to respond for real evacuation, $t_{\mathrm{EV}}$. According to these descriptions, they conclude that from the operational point of view, the following condition has to be satisfied for an effective tsunami early warning in near field:

$$
T_{\mathrm{TR}}>t_{\mathrm{SD}}+t_{\mathrm{TD}}+t_{\mathrm{ST}}+t_{\mathrm{WT}}+t_{\mathrm{EV}}
$$

where $T_{\mathrm{TR}}$ is the tsunami travel time.

Considering the extreme short arrival times, the classical approach in tsunami early warning systems described above based on KOERI's regional services cannot be utilized in a near-field system such as the Marmara Sea and a more direct approach is needed. In the case of Marmara, the only way to ensure the effectiveness of a tsunami early warning is couple the tsunami early warning system with the earthquake early warning system. 


\section{Istanbul earthquake early warning system}

The details of the Istanbul earthquake early warning (IEEW) system are given in Erdik et al. (2003), Mert et al. (2004), and in Alcik et al. (2009). The IEEW system is composed of 10 strong-motion stations located as close as possible to the Great Marmara Fault zone in "online" mode (Fig. 4). The continuous online data from these stations is used to provide real-time warning for emerging potentially disastrous earthquakes. Considering the complexity of fault rupture and the short fault distances involved, a simple and robust early warning algorithm, based on the exceedance of specified threshold time domain amplitude levels (band-pass-filtered accelerations and the cumulative absolute velocity), is implemented. The early warning information (consisting three alarm levels) are communicated to the appropriate servo shutdown systems of the recipient facilities, which will automatically decide proper action based on the alarm level. When a band-pass-filtered peak ground acceleration (PGA) and cumulative absolute velocity (CAV, the time integral of the absolute acceleration over the duration of the earthquake record) on any channel, in a given station, exceeds specific threshold values (currently set at $0.05,0.1$, and $0.2 \mathrm{~m} / \mathrm{s}^{2}$ ), it is considered a vote. Whenever there are votes from at least three stations for the respective threshold value within a 10-s (selectable) time interval, the respective alarm level is declared. 0.2, 0.4 and $0.7 \mathrm{~m} / \mathrm{s}$ alert levels based on bracketed CAV window approach $(\mathrm{BCAV}-\mathrm{W})$ have been proposed by
Alcik et al. (2009). Depending on the location of the earthquake (initiation of fault rupture) and the recipient facility, the alarm time can be as high as about $8 \mathrm{~s}$. The system is connected to the Istanbul Natural Gas Distribution Network, Istanbul Metropolitan Municipality, and Marmaray (submarine tube operated by the Turkish State Highways) for emergency traffic stopping.

In addition, KOERI started a new era in its observational capabilities by installing five sea-floor observation systems in the Sea of Marmara within the Sea Bottom Observatory (SBO) Project supported by Turkish Telecom, including broadband seismometers and differential pressuremeters, pressure transducer, strongmotion sensor, hydrophone, temperature measurement device, and flow meter (Fig. 1). The first sea bottom observation element was installed in December 2009 with real-time data transmission to KOERI. The seismic component of the sea floor observation system improves the azimuthal and spatial distribution of the existing network and reduces the early warning time and the minimum magnitude threshold down to 1.0 in the Marmara Sea, especially close to the northern branch of the NAFZ, which is the most active fault zone in the Marmara Sea (Meral Ozel et al. 2011).

\section{Proposed TEWS in Marmara}

In the case of Marmara, the only way to ensure the effectiveness of a tsunami early warning is couple the tsunami early warning system with the earthquake

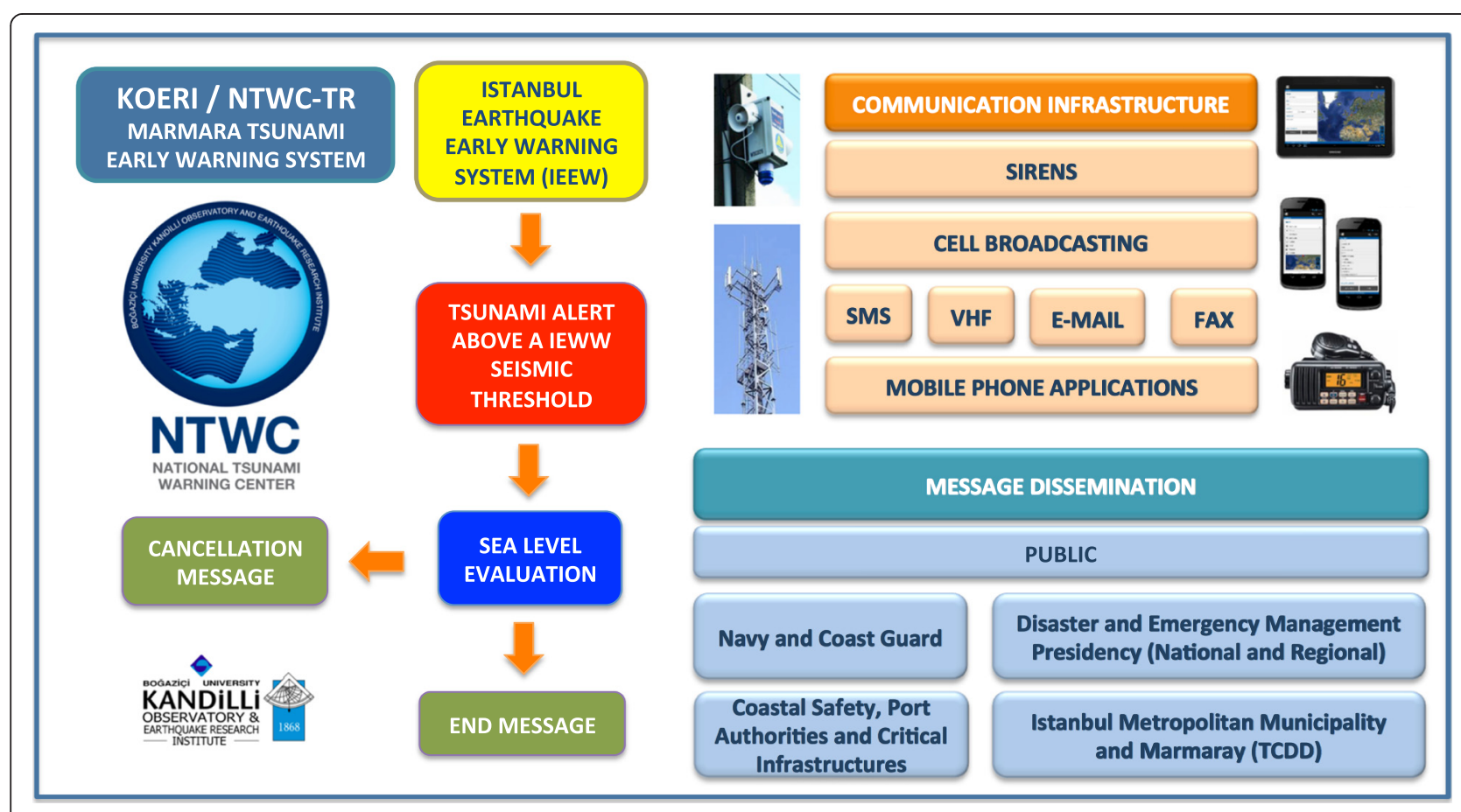

Fig. 4 Schematic representation of the proposed tsunami early warning system in the Marmara Sea 
early warning system, which would allow the elimination of $t_{\mathrm{SD}}$, the time needed for the determination of the earthquake focal parameters, and $t_{\mathrm{TD}}$, the time needed for the tsunami decision-making, through automation. These conditions are the main difference with a tsunami early warning system at the regional level. The proposed system for the Marmara Sea, as a modification to Papadopoulos and Fokaefs (2013), is strongly coupled with the IEEW system, also to address the possibility of an earthquake-triggered submarinelandslide-generated tsunami. In the proposed system, a tsunami warning would be disseminated automatically $1 \mathrm{~min}$ after the highest threshold of the IEEW with three votes has been received. This artificial 1-min delay would ensure to eliminate the possibility of a tsunami warning in case of a false alarm produced by the IEEW. The alert would be disseminated to the relevant authorities, such as the regional and the national Civil Protection Authority, Port Authorities and Critical Infrastructures, Coastal Safety, Istanbul Metropolitan Municipality, Navy and Coast Guard, and also to the public through various types of communication technologies such as sirens, cell and VHF broadcasting, e-mail, fax, and mobile phone applications (Fig. 4). The disseminated alert message functions as a reminder on the possibility of a tsunami generated by the earthquake that has been felt by the public already at the time the tsunami warning message has been issued. This way, the elimination of the time needed for the determination of the earthquake focal parameters, $t_{\mathrm{SD}}$, and the time needed for the tsunami decision-making, $t_{\mathrm{TD}}$, through automation and direct coupling with the IEEW, would reduce the total time needed to generate the alert to close to $1 \mathrm{~min}$. This setting would also eliminate $t_{\mathrm{ST}}$, the time needed for the transmission of the earthquake information and of the result of the tsunami decision to the operational center of the civil protection and other relevant authorities, through integrated system-to-system communications. Since the message would be issued through open communication channels to the public, it could be argued that $t_{\mathrm{WT}}$, the time needed to transmit warning information from the civil protection to the population, is eliminated, also. The total time for the dissemination of the alert would be less than $1 \mathrm{~min} . t_{\mathrm{EV}}$, the time needed by the authorities or the citizens to respond for real evacuation, depends solely on the level of awareness and preparedness of the end user, whether an authority or citizen. Nevertheless, it would be realistic to expect that citizens with high degree awareness of tsunami hazard in the Marmara Sea would respond in less than $1 \mathrm{~min}$. All of the reductions described above would lead to a maximum of 3 min total respond time by the end user. In the case of the citizen as the end user, the respond would need to be translated into action by not approaching the coastline for at least $2 \mathrm{~h}$, which has been defined as the maximum expected lifetime of a tsunami in Istanbul (OYO Pacific Consultants International Corporation et al. 2002).

It could be argued that, while the proposed system is adequate to issue a tsunami warning based on the strong ground motion through coupling to the IEEW system, a warning may not be issued for a tsunami due to a submarine landslide triggered by a weak ground motion. This could be considered as a drawback of the proposed system, but considering the history of earthquake-coupled tsunami observations in the Marmara region, it could be also argued that there is a low possibility for such event. In fact, the time interval of 5-15 min required to observe and process the tsunami signal on the differential pressuremeters in the deployed SBO would void the tsunami early warning.

\section{Conclusions}

The fact that a submarine landslide triggered by an earthquake could be the primary cause of a tsunami in the Marmara Sea, as indicated by the historical catalogues and previous studies, shows the importance of an earthquake early warning-coupled tsunami warning system without waiting for any focal mechanism parameter determination that may lead to an underestimation of the tsunami risk in the case of a strike-slip fault earthquake, which sets the dominant seismotectonic characteristic of the Marmara Sea. Through a tsunami warning system directly coupled with the Istanbul earthquake early warning system and based on system-to-system communications, an effective tsunami warning could be made within 3 min to ensure that citizens of the coastal areas would stay away from the direct coastline for at least $2 \mathrm{~h}$ after the earthquake has occurred. A precalculated comprehensive tsunami scenario database may assist the decision-making process with its use in evaluating sea-level data available to the tsunami warning system in real time.

The implementation of the proposed tsunami warning system would require commitment and collaboration of KOERI, national Civil Protection Authority (AFAD), and Istanbul Metropolitan Municipality as the primary stakeholders. In addition, the involvement of Port Authorities, Coastal Safety, Navy and Coast Guard, and municipalities of other coastal cities of the Marmara region should further strengthen this collaboration. Nevertheless, regardless of any model, the effectiveness of any tsunami early warning depends purely on the awareness and preparedness of the civil protection authorities and the public. Despite all recent efforts, in the absence of such awareness in the Marmara region, a possible earthquake-generated tsunami may increase the number of casualties simply due to the fact that, in the absence of post-disaster assembly 
areas inland, the residents of the coastal areas may storm to the shoreline, especially to Maltepe and Yenikapı landfill assembly areas, in an attempt to save lives from the structural damage due to the earthquake. Therefore, especially in Istanbul, there is a strong and urgent need to couple earthquake and tsunami disaster mitigation and management strategies and special focus should be given to the public education and preparedness based on this coupled strategy.

\section{Competing interests}

The author declares that he has no competing interests.

\section{Authors' information}

Dr. Öcal Necmioğlu is the coordinator of the KOERI-Tsunami Working Group for the establishment of a 24/7 operational National Tsunami Warning Center (NTWC-TR), also providing services to the Eastern Mediterranean, Aegean, and Black Seas as a Candidate Tsunami Service Provider (CTSP-TR) under the framework of the Intergovernmental Coordination Group for the Tsunami Early Warning and Mitigation System in the North-eastern Atlantic, the Mediterranean and connected seas (ICG/NEAMTWS) initiative, and a member of the ICG/NEAMTWS Steering Committee.

\section{Acknowledgements}

This study has benefited from the JICA/SATREPS Project "MarDiM: Earthquake and Tsunami Disaster Mitigation in the Marmara Region and Disaster Education in Turkey" supported by JICAVSATREPS and the Ministry of Development in Turkey, the EC-FP7 Projects "ASTARTE - Assessment, Strategy And Risk Reduction for Tsunamis in Europe" (Grant Agreement no: 603839) and "MARSite: New Directions in Seismic Hazard assessment through Focused Earth Observation in the Marmara Supersite" (Grant agreement no: 308417). I would like to thank Dr. Mehmet Yılmazer for his support in Fig. 1.

Received: 31 July 2015 Accepted: 16 January 2016

Published: 28 January 2016

\section{References}

Alcik H, Ozel O, Apaydin N, Erdik M (2009) A study on warning algorithms for Istanbul earthquake early warning system. Geophys Res Lett 36:L00B05. doi: 10.1029/2008GL036659

Altınok Y, Ersoy S (2000) Tsunamis observed on and near the Turkish coasts. Nat Hazards 21:185-205

Altınok Y, Tinti S, Alpar B, Yalçıner AC, Ersoy S, Bortolucci E, Armigliato A (2001) The tsunami of August 17, 1999 in Izmit Bay, Turkey. Nat Hazards 24:133-146

Altınok Y, Alpar B, Yaltirak C (2003) Sarkoy-Murefte 1912 Earthquake's Tsunami, extension of the associated faulting in the Marmara Sea, Turkey. J Seismol 7: 329-346

Altınok Y, Alpar B, Özer N, Aykurt H (2011) Revision of the tsunami catalogue affecting Turkish coasts and surrounding regions. Natural Hazards Earth System Science 11:273-293

Ambraseys NN (2002) Seismic sea-waves in the Marmara Sea region during the last 20 centuries. J Seismol 6:571-578

Ambraseys NN, Finkel C (1995) The seismicity of Turkey and adjacent areas. A historical review, 1500-1800, Eren Yayıncilık

Ambraseys NN, Finkel CF (1987) The Saros-Marmara earthquake of 9 August 1912. Earthq Eng Dyn Struct 15:189-211

Aochi H, Ulrich T (2015) A probable earthquake scenario near Istanbul determined from dynamic simulations. Bull Seismol Soc Am 105(3):1468-1475

Arel E, Kiper B (2000) The coastal landslide occurred by August 17, 1999 earthquake at Degirmendere (Kocaeli). Proceedings of Coastal Engineering 3rd National Symposium, October 5-7, 2000. Canakkale, Turkey., pp 45-55 (in Turkish)

Bohnhoff M, Bulu F, Dresen G, Malin PE, Eken T, Aktar M (2013) An earthquake gap south of Istanbul. Nat Commun 4:1999. doi:10.1038/ncomms2999

Cesmi-zade, M.R., 1766-1768, Cesmizade Tarihi (1766) In: B.S. Kütükoglu (ed.), Istanbul Fetih Cemiyeti Yayınları

Cetin KO, Isik N, Unutmaz B (2004) Seismically induced landslide at Degirmendere Nose, Izmit Bay during Kocaeli (Izmit)-Turkey earthquake. Soil Dyn Earthqu Eng 24:189-197
Erdik M (2013) Earthquake risk in Turkey. Science 341:72

Erdik M, Fahjan Y, Ozel O, Alcik H, Mert A, Gul M (2003) Istanbul Earthquake Rapid Response and the Early Warning System Department of Earthquake Engineering. Bull Earthq Eng 1:157-163

Ergintav S, Reilinger RE, Çakmak R, Floyd M, Çakır Z, Dogan U, King RW, McClusky S, Özener H (2014) Istanbul's earthquake hot spots: geodetic constraints on strain accumulation along faults in the Marmara seismic gap. Geophys Res Lett 41. doi:10.1002/2014GL060985

Gundogdu O (1986) Türkiye Depremlerinin Kaynak Parametreleri ve Aralarindaki \|liskiler(Source parameters of earthquakes in Turkey and their relationships), PhD-Thesis Istanbul University., p 120

Hancilar U (2012) Identification of elements at risk for a credible tsunami event for Istanbul. Nat Hazards Earth Syst Sci 12:107-119

Hebert H, Schindele F, Altınok Y, Alpar B, Gazioglu C (2005) Tsunami hazard in the Marmara Sea (Turkey): a numerical approach to discuss active faulting and impact on the Istanbul coastal areas. Mar Geol 215:23-43

Kaneko F (2009) A simulation analysis of possible tsunami affecting the Istanbul coast, Turkey, International Workshop on Tsunami Hazard Assessment and Management in Bangladesh

Meral Ozel N, Necmioglu O, Yalciner AC, Kalafat D, Mustafa E (2011) Tsunami hazard in the Eastern Mediterranean and its connected seas: toward a tsunami warning center in Turkey. Soil Dyn Earthq Eng 31(4):598-610

Mert A, Alçık H, ErdiK M, Gül M, Özel O, Fahjan Y (2004) Istanbul Earthquake Rapid Response And The Early Warning System, 13th World Conference on Earthquake Engineering Vancouver, B.C., Canada

Mihailovic J (1927) Memoir-Sur les Grands Tremblement de Terre de la Mer de Marmara, Beograd., pp 215-222

OYO Pacific Consultants International Corporation, Japan International Cooperation Agency (JICA), Istanbul Metropolitan Municipality (IMM) (2002) The study on a disaster prevention/mitigation basic plan in Istanbul including seismic microzonation in the Republic of Turkey - Final Report

Oztin F (1994) 10 Temmuz 1894 Istanbul Depremi Raporu, T.C. Bayindirlik ve Iskan Bakanligi, Afet Isleri Genel Mudurlugu, Deprem Arastırma Dairesi, (Report on 10 July 1894 Istanbul Earthquake by Ministry of Public Works and Settlement, General Directorate of Disaster Affairs, Department of Earthquake Research), Ankara

Oztin F, Bayülke N (1991) Historical earthquakes of Istanbul, Kayseri, Elazıg. In: Proceedings of the workshop on historical seismicity and seismotectonics of the Mediterranean region, 10-12 October 1990 (Istanbul), Turkish Atomic Energy Authority, Ankara., pp 150-173

Papadopoulos GA, Fokaefs A (2013) Near-field tsunami early warning and emergency planning in the Mediterranean Sea. Res Geophys 3:24-31

Parsons T (2004) Recalculated probability of $M>7$ earthquakes beneath the Sea of Marmara, Turkey. J Geophys Res. 109. doi:10.1029/2003JB002667

Rothaus R, Reinhardt E, Noller J (2004) Regional considerations of coastline change, tsunami damage and recovery along the southern coast of the Bay of I'zmit (The Kocaeli (Turkey) earthquake of 17 August 1999). Nat Hazards 31:233-252

Tinti S, Armigliato A, Manucci A, Pagnoni G, Zaniboni F, Yalciner AC, Altınok Y (2006) The generating mechanisms of the August 17, 1999 Izmit bay (Turkey) tsunami: regional (tectonic) and local (mass instabilities) causes. Mar Geo 225:311-330

Yalciner AC, Altınok Y, Synolakis CE (2000) Tsunami waves in Izmit Bay after the Kocaeli Earthquake. Earthquake Spectra, Kocaeli, Turkey Earthquake of August 17, 1999 Reconnaissance Report, Special Issue Supplement to Professional Journal of Earthquake Engineering Research Institute vol. 16, pp. 55- 62

Yalciner AC, Imamura F, Kuran U, Cakiroglu Y, Ozbay I, Erdinc E, Durmusoglu O, Altınok Y, Alpar B (2001a) An integrated model on the generation and propagation of tsunamis in the surrounding seas around Anatolia-Turkiye cevresi denizlerde tsunami dalgasi hareketi icin bilesik model olusturulmasi. Final Report of Basic Research Project No: TUBITAK-YDABCAG-60

Yalciner AC, Kuran U, Altınok Y, Alpar B, Ersoy S (2001b) Historical earthquakes and associated tsunamis in the Aegean Sea-Turkiye kiyilarinda tarihsel depremler ve onlara iliskin tsunamlerin izlerinin arastirilmasi. Final Report of Basic Research Project No: TUBITAK-INTAG-827

Yalciner AC, Synolakis CE, Alpar B, Borrero J, Altınok Y, Imamura F, Tinti S, Ersoy S, Kuran U, Pamukcu S, Kanoglu U (2001C) Field surveys and modeling of the 1999 Izmit tsunami. Proceedings of the International Tsunami Symposium, August 7-10, 2001, Seattle, Washington, USA 